\title{
Research on Capital Cost Analysis of State Owned Enterprises in China
}

\author{
Pei Wang ${ }^{1, a}$ \\ Department of Economics, China University Of Geosciences Great Wall College, Baoding, China \\ a724388082@qq.com
}

Keywords: State-owned enterprises; Capital cost; Estimation; Empirical Research

\begin{abstract}
The Capital cost is one of the most important concepts in the development of state-owned enterprises, which directly determines the enterprise value and is widely used in terms of investment and financing decisions, thus plays an important role in the company's financial goals. Estimating the capital cost for businesses accurately is significant to corporate capital for financing decisions, capital investment decisions, assessment and management of working capital and other corporate performance. In this paper, taking state-owned enterprises as the research object and making a clear understanding of the structure and capital cost in the form of state-owned enterprises, focusing on the analysis method to estimate the capital cost of state-owned enterprises and taking state-owned listed companies as example to carry out empirical research.
\end{abstract}

\section{Introduction}

State-owned enterprises play a very important role in China's economic development, which are directly related to the development of national economy and have made tremendous contributions to China's economic development ${ }^{[1]}$. However, with the deepening of China's state-owned enterprise reform and the socialist market economy are maturing, China's state-owned enterprises are facing tremendous challenges and opportunities. But the methods to meet the challenges are not effective and efficient enough especially is not yet clear understanding for the capital cost, which has an important impact on project finance and corporate performance evaluation and other matters. For example, often taking simply bank lending rates as part of its capital cost leads to blind investment in many state-owned enterprises and low efficiency of state-owned assets and is not conducive to increasing the value of state assets. Therefore, this paper studies the capital cost of state-owned enterprises for analysis has important theoretical and practical significance. On the one hand, the analysis of the capital cost of state-owned enterprises can effectively curb excessive investment, increase the use of capital and play the advantages of performance evaluation. On the other hand, estimating the capital cost for businesses accurately has great significance to capital financing decisions, capital investment decisions, working capital management and business performance and so on ${ }^{[2,3]}$.

In this paper, the capital cost connotation and composition are cleared, method to estimate the capital cost are analyzed and then select the appropriate estimation method of the capital cost for state-owned enterprises from the basic theory of the capital cost. Finally, the state-owned listed companies are taken as example to carry out empirical study.

\section{The Basic Theory of the Capital Cost}

\section{Connotation Capital Cost}

The concept of capital cost for the first time that was proposed by Alfred Marshall in 1890, and then continues through the rich, the theory has been relatively complete. Currently, the generally accepted definition of costs of capital is the definition in "new monetary and financial Palgrave Dictionary", that is the capital cost is the expected rate of return that investors of the business assets 
asked for and the company's goal to maximize value for the capital cost as the manager of the discount rate or the minimum rate of return on investment project evaluation. From a business point of view, the capital cost refers to the cost of the acquisition and possession of capital companies for pay, including financing costs and occupancy costs of capital. From an investor perspective, capital cost is the return on the capital investment required for a particular project, or you can call the opportunity cost, the degree of risk and investment projects was directly proportional relationship. The nature of the capital cost consists of two aspects: First, in fact, the capital cost is an opportunity cost; the decisive factor of the level of corporate capital cost is rate of return requirements of investors.

\section{Composition and Form of the Capital Cost}

Capital cost refers to enterprises pay for the cost and use of capital, typically includes financing costs and the charges ${ }^{[4]}$. Among them, Financing costs refer to the costs of enterprises in the process of raising capital to acquire funds incurred, such as fee bank borrowings, printing costs issue shares, bonds and other securities, assessment fee, notary fees, publicity expenses and underwriting fees and so on. And charges refer to the use of the funds raised about this process paid to donors, such as interest on bank loans and bonds and stock dividend and so on.

Capital cost has multiple application forms, which must use different forms to solve different problems. When comparing various financing, using individual cost of capital, such as borrowing capital cost, debt capital cost rate, the cost of common equity capital ratio, preferred capital cost, retained earnings capital cost. When carry out corporate capital structure decision, using a comprehensive cost of capital. When decides the increase funding structure, use the edit capital cost. In this paper, analyzing the capital cost of state-owned enterprises and mainly focus on comprehensive capital cost analysis and calculation.

\section{The Calculation Methods of Capital Cost of State-owned Enterprises}

On the capital cost calculation method, Western scholars have used basic model to estimate the capital cost, however, our financial circles neither solve the problem capital cost estimate, nor can construct a reasonable estimation model of capital cost. Besides, there is little literature about capital cost estimate of state-owned enterprises. Therefore, in this paper, choosing the basic model that western scholars often use to calculate the capital cost of the state-owned enterprises, that is calculate the debt and cost and equity cost in the capital cost and then summary results of them to figure out the weighted average capital cost.

\section{Calculation of the Debt Cost}

Debt capital financing is a low-cost business financing, because of this, many companies are operating in debt. Based on the specific circumstances of each country, the two most important corporate financing are bank loans and corporate bonds. Based on the connotation of debt capital financing, the cost of debt capital refers to the cost of capital level after discounting the effect of income tax. The method of estimating the cost of debt including: Using the yield to maturity of the bond public offering and then obtaining the estimated pre-tax cost of debt, that is to say the yield to maturity is the cost of debt publicly issued bonds; Using a risk-additive method to estimate the pre-tax cost of debt, that is based on the basis of the country's debt rating to determine a degree of risk premium required to determine the cost of debt according to these target.

\section{Estimated Cost of Equity Capital}

The accuracy of estimation of the equity capital cost has a direct impact on investors and the whole company's financial decisions. Therefore, estimate the cost of equity capital correctly is related to decision-making and business prospects of companies. Currently, methods commonly used in equity capital cost estimation including: Capital Asset Pricing Model, Gordon model and Fama-French three-factor model. Among them, there are some difficulties in estimating the parameter of Gordon model and the results are likely to be affected. Fama-French three-factor model is subject to special equity structure of China, the results prone to bias. Capital Asset Pricing Model are the most widely used in the realm of theory and practice, having strong applicability. Considering rationality and 
operability of the method and according to China's actual conditions, so in this paper, Capital Asset Pricing Model is selected as the estimation method to estimate the cost of equity capital.

The capital asset pricing model offers the method to determine the stock given the expected rate of return. The expected rate of return of the stock is equal to the cost of equity capital stock. The specific formula is as follows:

$$
K_{E}=E\left(R_{i}\right)=R_{f}+\beta_{i}\left(E\left(R_{m}\right)-R_{f}\right)
$$

Among them, $E\left(R_{i}\right)$ represents the expected yield securities, $R_{f}$ represents risk-free rate, $\beta_{i}$ represents securities market risk factor (that is number of risks), $E\left(R_{m}\right)-R_{f}$ represents market risk premium.

According to this formula, the Cost of Equity Capital stock equals the risk-free rate and the risk of compensation. The expected return rate of stock depends on the risk-free interest rate, market risk premium and the risk level of the stock market. Therefore, only define and measure these three factors scientifically, can estimate the expected return rate of the stock, and then determine the cost of equity capital.

\section{Estimation of Weighted Average Capital Cost}

The overall cost of capital of a company reflects the required return rate of its overall assets. For most companies, their normal operating capital required is actually a combination of different sources of capital. It is necessary to determine the total cost of all long-term capital companies for financing decision analysis-- Weighted Average Capital Cost (WACC). The weighted average capital cost is generally based on the individual cost of capital as a proportion of total capital weights to determine the average weighted cost of capital for individual, the formula is as follows:

$$
W A C C=K_{d}(1-T) D / V+K_{s} S / V
$$

Wherein, D represents liability, $\mathrm{S}$ represents equity capital, $K_{d}$ represents debt cost, $K_{s}$ represents equity cost, $\mathrm{T}$ is the marginal income tax rate. There are usually three ways in determining the proportion of individual capital to total capital that is book value ratio, the ratio of the market value and the target value of the ratio. In this paper, the book value ratio was chosen to identify the proportion, which is conducive to reflect the conditions when financing and to reflect funders and corporate earnings on the prevailing market interest rate risk and projects equilibrium price.

\section{Empirical Research}

\section{Sample Description}

The data in this paper when estimating the capital cost used in state-owned enterprises is from Genius database, research interval 2010-2014, the study subject is a state-owned enterprises listed companies and shares of Chinese companies to define the proportion of more than $30 \%$, and excluding abnormal operating conditions and PT ST companies, excluding missing data business.

\section{Calculation of the Debt Cost}

After investigating, the debt financing of the selected company is mainly based on bank borrowings, and there is a very small proportion of bond financing. Therefore, bank lending rates can be used as a reasonable reference factors. Besides, since China has not yet fully liberalized bank lending rates, lending rates used by different companies are basically the same. Therefore, in this paper, we select business short-term lending rates of six months to a year announced by the central bank to estimate sample enterprises. If the central bank makes some adjustment, then calculate based on the weighted average annual interest rate. In the end, the debt capital cost estimates of sample enterprises in 2010-2014 are shown in Table 1.

Table 1 The debt capital cost estimates of sample enterprises in 2010-2014

\begin{tabular}{cccccc}
\hline Years & 2010 & 2011 & 2012 & 2013 & 2014 \\
\hline Nominal debt cost & $5.31 \%$ & $5.31 \%$ & $5.58 \%$ & $5.85 \%$ & $6.67 \%$ \\
Actual debt cost & $4.11 \%$ & $1.41 \%$ & $3.78 \%$ & $4.35 \%$ & $1.87 \%$ \\
\hline
\end{tabular}




\section{The Estimation of Equity Cost Based on CAPM}

According to the formula listed above, we should select capital asset pricing model in the risk-free rate, market risk premium and the stock market reasonably to accurately calculate the equity capital cost.

First, choose the average value $3.608 \%$ of the 10 -year treasury rate since 2006 as an estimated equity capital cost risk-free return rate.

Second, according to the research results of Damodaran, estimated the market risk premium trend, and then obtained the estimated result of the market risk premium of China based on the US equity risk premium is $6.202 \%$.

Finally, choose the month of sample with respect to changes in the index of stock returns to do some yield regression. And determine the market risk parameters of sample enterprises. The specific regression equation is as follows:

$$
R_{i j}=a+b R_{m j}+\varepsilon_{j}
$$

Wherein, $R_{i j}$ represents the yield levels of stock $\mathrm{i}$ in the j-month. $R_{m j}$ represents the return level of index.

In summary, we can obtain the equity capital cost of the sample enterprises; they were shown in Table 2.

Table 2 The estimation of equity cost based on CAPM

\begin{tabular}{cccccc}
\hline Years & 2010 & 2011 & 2012 & 2013 & 2014 \\
\hline Nominal debt cost & $7.99 \%$ & $8.92 \%$ & $7.36 \%$ & $7.06 \%$ & $10.82 \%$ \\
Actual debt cost & $6.79 \%$ & $5.02 \%$ & $5.56 \%$ & $5.56 \%$ & $6.02 \%$ \\
\hline
\end{tabular}

The Estimation of the Weighted Average Capital Cost of State Owned Enterprises

According to estimation result of the debt capital cost and the equity capital cost, estimating the weighted average capital cost of sample enterprises using the weighted average capital cost estimation formula, and the results are shown in Table.3.

Table.3 the result of estimation of the WACC of state owned enterprises

\begin{tabular}{cccccc}
\hline Years & 2010 & 2011 & 2012 & 2013 & 2014 \\
\hline Nominal WACC & $5.87 \%$ & $6.24 \%$ & $5.46 \%$ & $5.21 \%$ & $7.50 \%$ \\
Actual WACC & $4.67 \%$ & $2.34 \%$ & $3.66 \%$ & $3.71 \%$ & $2.70 \%$ \\
\hline
\end{tabular}

From this table, we know that, in recent years, the WACC trends of sample enterprises are relatively flat, and the estimation result of equity capital cost is higher than debt capital cost and weighted average capital cost, and the value of debt capital cost and weighted average capital cost are very close. This is consistent with the nature of the financial theory defined in preference for equity financing that is to say since equity capital cost does not have a tax credit effect, the equity cost is higher than debt capital cost.

\section{Conclusion}

The capital cost is the minimum return rate demanded by investors, State-owned enterprises should establish awareness of the capital cost and focus on compensation of national shareholders and other shareholders' return rate, which not only to safeguard national interests and protect the interests of small investors reflect, but also conducive to value-added of state-owned enterprises.

\section{References}

[1] Wang Ping, Zou Ying. State-owned Enterprises, Government Shareholder and Cost of Capital Financial Thoughts on Deepening SOE Reform[J]. Journal of Capital University of Economics and Business, 2012(1): 55-61. 
[2] Yan Tian. Listed companies and state-owned enterprises capital cost estimate and comparative analysis - based on the estimated cost of capital CAPM[J]. China Academic Journal Electronic Publishing House, 2008(4): 86-89.

[3] Yan Tian. Analysis of financial goals based on the cost of capital owned enterprises[J]. Productivity Research, 2008(7): 131-133.

[4] Feng Rui. A Study on Cost of Capital of the State-owned Enterprises - A Case Study of China Railway Construction Corporation Limited[D]. Beijing, Research Institute for Fiscal Science, Ministry of Finance, People’s Republic of China, 2012, 13-17.

[5] http://www.stern.nyu.edu/ adamodar 